\title{
RIGHT TO COUNSEL IN CRIMINAL POST-CONVICTION REVIEW PROCEEDINGS
}

Recently, in Douglas v. California, ${ }^{1}$ the United States Supreme Court held that the equal protection clause of the fourteenth amendment requires states to appoint counsel for indigents upon request on their first appeal as of right from a criminal conviction. ${ }^{2}$ Appellants Douglas and Meyes were convicted of thirteen felonies. They appealed as of right to a California district court of appeal and requested the appointment of counsel. Under the California rule for appointment of counsel on appeal, the appellate court could decline to appoint counsel only if, after an independent investigation of the record, it concluded that counsel would be of no value to either the defendant or the court. ${ }^{3}$ The appellate court in Douglas, after such ex parte examination of the record, had declined to appoint counsel for the appellants, stating that no good whatever would be served by appointment. The United States Supreme Court reversed, declaring that "where the merits of the one and only appeal an indigent has as of right are decided without benefit of counsel ... an unconstitutional line has been drawn between rich and poor."4 The Court relied on cases beginning with Griffin $v$. Illinois ${ }^{5}$ which held that states cannot foreclose an effective appeal from a defendant who is unable to pay a filing fee or purchase a transcript. ${ }^{6}$ The purpose of this Comment is to show the immediate effect of Douglas on state and federal appellate proceedings, to explore the possible effects of the decision in collateral attack proceedings, and to discuss the problems created by the demand for assistance of counsel.

1372 U.S. 353 (1963) (6-to-3 decision).

2 Prior to Douglas the duty imposed on the courts to appoint counsel for indigents did not extend beyond the trial level and was developed through the sixth amendment for the federal courts and the due process clause of the fourteenth amendment for the states. The sixth amendment imposes on the federal courts the duty to appoint counsel for indigents in all criminal proceedings unless the indigent waives his right to counsel. Johnson v. Zerbst, 304 U.S. 458 (1938). Johnson, however, was seen as only guaranteeing the right to assistance of counsel at the trial and having no apphication to appeal. Thompson v. Johnson, 160 F.2d 374 (9th Cir.), cert. denied, 331 U.S. 853 (1947).

It was first held that due process only required states to afford counsel to indigents at the trial if lack of counsel would result in "a denial of fundamental fairness, shocking to the umiversal sense of justice . . . ." and so prevent a fair trial. Betts v. Brady, 316 U.S. 455,462 (1942). The application of this flexille standard meant that the need for counsel had to be shown in each particular case. This gave rise to much litigation. See generally BEANEY, RIGET to Counsed in American Courts (1955); Kamisar, Betts v. Brady Twenty Years Later, 61 Mich. L. REv. 219 (1962).

It was not until Gideon v. Wainwright, 372 U.S. 335 (1963), that the guarantee of counsel in the sixth amendment was held to be a fundamental right to a fair trial and so a necessary element of due process in felony cases. Thus, the states as well as the federal courts are now required to appoint counsel for an indigent at the trial in serious criminal cases unless he waives his right to counsel.

3 People v. Hyde, 51 Cal. 2d 152, 154, 331 P.2d 42, 43 (1958).

4 Douglas v. California, 372 U.S. 353,357 (1963).

5351 U.S. 12 (1956).

${ }^{6}$ The right to appeal from a criminal conviction in both state and federal courts is not required by due process. McKane v. Durston, 153 U.S. 684 (1895); cf. Griffin v. Illinois, 351 U.S. 12 (1956). But when appellate review is offered, the procedure must conform to the requirements of due process and equal protection. Dowd v. United States ex rel. Cook, 340 U.S. 206 (1951); Cole v. Arkansas, 333 U.S. 196 (1948); Cochran v. Kansas, 316 U.S. 255 (1942); cf. Ortega v. Ragen, 216 F.2d 561 (7th Cir. 1954). In Griffin v. Mlinois, 351 U.S. 12 (1956), the Supreme Court held that equal protection requires states to give indigents equal access to appellate review by providing an adequate transcript for review of alleged trial errors. Under 
EFFECT OF DOUGLAS ON APPELLATE PROCEEDINGS

\section{A. Initial State Appeals}

The immediate effect of Douglas on state direct review proceedings is to require appointment of counsel for indigents upon request for their first appeal as of right from a criminal conviction, regardness of the merits of the appeal ${ }^{\tau}$ and presumably regardless of the seriousness of the offense. ${ }^{8}$ Since the indigents in Douglas had requested counsel and the Court does not state that a request is unnecessary, the holding does not appear to require an affirmative offer of counsel as is required at the trial. ${ }^{9}$

The major problem raised by Douglas concerns frivolous appeals. Apparently Douglas allows states to screen appeals for merit by entertaining motions to dismiss before considering briefs or oral argument as long as rich and poor appellants are treated alike. ${ }^{10}$ To the extent, however, that state practice is to review all paid appeals after briefing and oral argument regardless of merit, the indigent must also be afforded the full benefit of counsel's briefing and oral argument. ${ }^{11}$

Illinois law, only the mandatory or common law record, consisting of indictment, arraignment, plea, trial and judgment, were automatically brought up for review. Most reversals on appeal are based on errors not discoverable in the mandatory record, such as errors in the instructions to the jury or comments on the evidence. To bring any additional record up for review, a bill of exceptions is necessary and this is usually impossible to produce without a full transcript. Since tbe appellant was required to purchase this additional transcript, the indigent was effectively foreclosed from a meaningful review automatically given to those who could afford the transcript. See Brief for Petitioner, pp. 12-15, Griffin v. Illinois, 351 U.S. 12 (1956). The Griffin principle was apphed retroactively. Eskridge v. Washintgon State Board of Prison Terms and Paroles, 357 U.S. 214 (1958). Cf. Patterson v. Medberry, 290 F.2d 275 (10th Cir.), cert. denied, 368 U.S. 839 (1961). Justice Frankfurter believed that Grifin should speak only prospectively because of practical concerns of administration. Griffin v. Illinois, 351 U.S. 12, 25 (1956) (separate opinion).

The equality of access principle was subsequently applied to otber post-conviction remedies of: (1) petitioning for a discretionary appeal after one appeal has already been considered, Burns v. Ohio, 360 U.S. 252 (1959); see Douglas v. Green, 363 U.S. 192 (1960); (2) petitioning for a writ of habeas corpus, Smith v. Bennett, 365 U.S. 708 (1961); see Barber v. Gladden, 210 Ore. 46, 298 P.2d 986 (1956); and (3) appealing from a denial of a writ of coram nobis, Lane v. Brown, 372 U.S. 477 (1963) ; accord, McCrary v. Indiana, 364 U.S. 277 (1960).

7 See Application of Shepherd, ........ A.C.A. ......., 32 Cal. Rptr. 131 (1963); In re Miller, A.C.A. ........, 30 Cal. Rptr. 784 (1963); Donald v. State, 154 So. 2d 357 (Fla. App. 1963); cf. McIntosh v. Commonwealth, 368 S.W.2d 331 (Ky. 1963). In Vasquez v. District Court, 59 A.C. 606, 381 P.2d 203, 30 Cal. Rptr. 467 (1963), the California Supreme Court issued a writ of mandamus compelling an appellate court to appoint counsel for an indigent without any prior consideration of the merits.

8 The Court did not indicate that the seriousness of the offense was a controlling consideration. Compare Gideon v. Wainwright, 372 U.S. 335 (1963), concerning the right to counsel at the trial.

O See McIntosh v. Commonwealth, 368 S.W.2d 331 (Ky. 1963), holding that although due process requires that indigents inust be advised of their right to counsel at the trial, equal protection requires appointment of counsel only upon request and does not require that an offer be made.

10 In People v. Wallace, 217 A.C.A. 489, 31 Cal. Rptr. 697 (1963), the court appointed counsel and then upon motion dismissed the appeal as frivolous without a full hearing. The court indicated it was following federal in forma pauperis practice, citing Ellis v. United States, 356 U.S. 674 (1963).

11 This is the requirement for current federal practice. See note 30 infra and accompanying text. 
Providing this full representation for all indigents regardless of the merit of the appeal raises problems when the appeal is so frivolous that the appointed counsel can find no merit upon which to base a tenable argument. Should counsel be required to serve after he has investigated the record, examined his client and other witnesses and found that there is no merit in the appeal or should the court be able to dismiss counsel and decide on the merits with only the aid of the transcript and pro se briefs? An appointed counsel should not be required to form arguments which he believes to be completely baseless. ${ }^{12}$ Yet an appellant who can afford to hire counsel has the opportunity to search for one who believes he can present some worthy arguments. Douglas gives no express answer to the question of whether equal protection is satisfied by the appointment of one counsel or whether some further effort to provide the indigent with a counsel willing to accept the case is necessary. The Court, however, contrasted California practice with the virtues of the federal practice of appointing counsel in every case for an appeal from the trial court's denial of leave to appeal without costs. If the Court here implies that federal practice is sufficient to comply with the demands of equal protection, then it should be noted that federal courts can discharge appointed counsel without appointing another if, after investigation, counsel finds no argument he can raise on appeal and the appellate court agrees with his view of the case. ${ }^{13}$ Moreover, smce the main inequality aimed at in Douglas is the indigent's lack of benefit of counsel's examination of the record, research of the law, and marshalling of arguments, ${ }^{14}$ it is doubtful that when an indigent has been given this benefit through one appointed counsel, failure to appoint other counsel will be branded as invidious discrimination. ${ }^{15}$ Appointment of a second counsel should not be required by equal protection but should be left to the discretion of the court. Equal protection surely does not demand that a court find counsel willing to accept an appeal in every case, since it should not be assumed that hired counsel can find appealable merit in every paid appeal. A court, of course, is pre-judging the merits, but with the aid of counsel. Appointing only one counsel seems to be the present California practice. ${ }^{16}$ Appellate courts, however, may in their discretion go further than the

12 See People v. Brown, 55 Cal. 2d 64, 69, 357 P.2d 1072, 1975, 9 Cal. Rptr. 816, 819 (1960) (separate opinion of Traynor, J.).

13 Ellis v. United States, 356 U.S. 674 (1958); Douglas, In Forma Pauperis Practice in the United States, 2 N.H.B.J. 5, 7 (1959); see generally Boskey, The Right to Counsel in Appellate Proceedings, 45 MinN. L. Rev. 783, 794-96 (1961).

14372 U.S. at 358.

15 The Court in Douglas noted that states can provide for some differences consistently with due process and equal protection. Id. at 356-57.

${ }^{16}$ E.g., People v. Chavez, 218 A.C.A. 754, 32 Cal. Rptr. 450 (1963); People v. Welch, 218 A.C.A. 440, 31 Cal. Rptr. 926 (1963) ; People v. Adams, 218 A.C.A. 438, 32 Cal. Rptr. 403 (1963) ; People v. Price, 218 A.C.A. 348, 32 Cal. Rptr. 599 (1963); People v. Scott, 218 A.C.A. 133, 31 Cal. Rptr. 925 (1963). The appellate court reviews the transcript and does not consider the report of appointed counsel as binding on the defendant or as limiting the court's consideration of the case. People v. Taylor, 218 A.C.A. 339, 32 Cal. Rptr. 384 (1963).

Practice differs, however, and soine courts usually appoint second counsel. Interview with Presiding Justice, California District Court of Appeal, First District, Division One, in San Francisco, October, 1963, and with Presiding Justice, California District Court of Appeal, First District, Division Three, in San Francisco, October, 1963. In the absence of any specified duty, perhaps the best guide would be the federal practice outlined above. The appellate court could still appoint second counsel in its discretion if it disagreed with the opinion of first counsel or if the seriousness of the sentence inposed warranted extremely close attention to the appeal. 
Constitution requires and may find it advantageous in some cases to apoint a second counsel to assure that there is no possible basis for appeal that can be raised. ${ }^{17}$ Furthermore, appointed counsel should always be required to act principally as an advocate for the indigent and not as amicus curiae to the court. ${ }^{18}$ Such representation will reduce the need to appoint second counsel.

\section{B. Federal Appeals}

Although Douglas applies directly only to the states, it will no doubt have an effect on the federal practice of appointing counsel on appeal. Although the Constitution does not apply equal protection explicitly to federal action, the guarantee of equal protection has been applied to the federal government through the due process clause of the fifth amendment. ${ }^{19}$ Moreover, Douglas rested on the guarantees of fair procedure inherent in due process as well as on the equal protection clause. ${ }^{20}$ Because a direct appeal from a district court's judgment of conviction is a matter of right, ${ }^{21}$ the type of proceeding is the same as that encountered in Douglas.

Through the in forma pauperis statute, ${ }^{22}$ Congress has empowered the federal courts to request an attorney to represent an indigent and to authorize any action or proceeding for an indigent, including an appeal, without payment of fees, costs, or security. Congress, however, also adopted a system of screening appeals by providing that an appeal may not be taken in forma pauperis if the trial court certifies that it is not taken in good faith. ${ }^{23}$ Good faith is determined solely by the merits of an appeal, ${ }^{24}$ and so the same court that convicts and sentences the indigent is required to make an evaluation of the appeal. If the trial court grants leave to appeal in forma pauperis by certifying that the appeal is taken in good faith, then counsel is probably appointed ${ }^{25}$ and the appeal is docketed in the court

17 In one California appellate court, out of fifteen second counsel appointed during one term, two got reversals. Interview with Justice Peters, Associate Justice, California Supreme Court, in San Francisco, September, 1963. This means that two out of fifteen appointed counsels were wrong in their judgment of the case.

18 The federal courts demand the role of advocacy from appointed counsel. It is stressed that he should not act as a friend of the court but should tell the court the appeal is without merit only when he lias in good faith done all reasonably possible to find grounds for appeal. See authorities cited note 13 supra.

19 In Bolling v. Sbarpe, 347 U.S. 497 (1954), the Court stated that "the 'equal protection of the law' is a more explicit safeguard of prolibited unfairness than 'due process of law,' and, therefore, we do not imply that the two are always interchangable phrases. But, as this Court has recognized, discrimination may be so unjustifiable as to be violative of due process." Id. at 499. See Hyser v. Reed, 318 F.2d 225 (D.C. Cir. 1963) (separate opinion). Cf. Coppedge v. United States, 369 U.S. 438, 446-47 (1962). See generally Antieau, Equal Protection Outside the Clause, 40 CaLrF. L. Rev. 362 (1952).

20372 U.S. at 360-61 (Harlan, J., dissenting).

2128 U.S.C. \$\$ 1291, 1294 (1948); FED. R. CRIM. P. 37 (a); see Coppedge v. United States, 369 U.S. 438,441 (1962).

2228 U.S.C. § 1915 (1948), as amended, 28 U.S.C. \$ 1915 (Supp. 1959).

23 Ibid.

24 Coppedge v. United States, 369 U.S. 438 (1962); Ellis v. United States, 356 U.S. 674 (1958).

${ }_{25}$ Although the United States Supreme Court has not specifically leeld that such appointment by the trial court is required, there is no reason for distinguishing between situations in which the trial court grants leave to appeal in forma pauperis and where the appellate court las granted the opportunity. When the court of appeals grants leave to proceed in forma pauperis and considers the merits of the appeal, counsel must be appointed. See Coppedge v. United States, 369 U.S. 438 (1962). 
of appeals for consideration on the merits. If the trial court denies leave to appeal in forma pauperis, the indigent is foreclosed from an appeal because of the required fees. The trial court's decision, however, is reviewable before the court of appeals, ${ }^{26}$ and it is well settled that the sixth amendment imposes on the federal courts a requirement to appoint counsel for indigents, upon request, for such review. $^{27}$

The United States Supreme Court has shown concern over inequality in treatment of indigents after counsel lias been appointed. The Court has dictated the standards to be used by the courts of appeals on such review in an effort to equalize the treatment of rich and poor appellants. It has declared that in evaluating the trial court's application of the good faith test the court of appeals must not interpret the test as requiring a prehminary showing of any minimum degree of merit, but should regard it as the equivalent of the test used in considering a motion to dismiss a paid appeal as frivolous; ${ }^{28}$ appeal in forma pauperis must be allowed if there is any issue presented "not clearly frivolous."20 In order to assure complete equality of treatment, the same benefit of counsel should be afforded the indigent before decision on the in forma pantperis appeal as is allowed the wealthy appellant before the motion to dismiss is acted upon. In Coppedge $v$. United States ${ }^{30}$ the United States Supreme Court required such a practice. The Court said that if it were the practice of the courts of appeals to defer rulings on motions to dismiss until after considerations of the record, briefs, and oral arguments, then the indigent must be afforded the same procedural rights and the courts must consider the briefs and arguments of appointed counsel before deciding whether to grant a free appeal. Since it now seems to be the general practice of the courts of appeal to defer such rulings as to paid appeals, ${ }^{31}$ the indigent in nearly all cases should be granted the full benefit of counsel's briefing and oral argument. ${ }^{32}$

Although the United States Supreme Court has apparently provided in these procedures for appointment of counsel which would satisfy Douglas' requirements,

26 See statute cited note 22 supra; Coppedge v. United States, 369 U.S. 438 (1962).

27 Johnson v. United States, 352 U.S. 565 (1957). Cf. Douglas v. California, 372 U.S. 353 (1963); Robinson v. United States, 304 F.2d 805 (8th Cir. 1962); United States v. Mallison, 250 F.2d 792 (2d Cir. 1957).

28 Ellis v. United States, 356 U.S. 674-75 (1958). The requirement is considered to be a result of statutory interpretation and not of constitutional demand. See Hyser v. Reed, 318 F.2d 225 (D.C. Cir. 1963).

20 Coppedge v. United States, 369 U.S. 438, 446 (1962).

30 Ibid.

31 E.g., Keinington v. United States, 307 F.2d 632 (D.C. Cir. 1962) ; Robinson v. United States, 304 F.2d 805 (8th Cir. 1962). But see Hill v. United States, 294 F.2d 562 (8th Cir. 1961).

"The virtual non-existence of reported cases in which a criminal appeal has been dismissed as frivolous suggests strongly that virtually every defendant convicted in a federal court can now have that conviction reviewed by a Court of Appeals." Ehrenhaft, Are the Paupers Pampered? Indigent Appellants in the Federal Courts, 46 A.B.A.J. 646, 647 (1960).

32 As long as these screening procedures exist, the only way indigents can be afforded equal benefit of the review process is through ungrudging acceptance of the Coppedge requirement by federal prosecutors and courts of appeals. There is evidence that federal prosecutors often oppose motions for leave of appcal in forma pauperis and file motions to dismiss the appeal as frivolous without regard to the Supreme Court's interpretation of "good faith" in Coppedge. Jones v. United States, 266 F.2d 924, 925 n.2 (1959). See Report of the Attorney General's Committee on Poverty and the Administration of Crintinal Justice, ch.4, pp. 98-104 (1963).

For an example of a court of appeals' uncertainty about and apparent dissatisfaction with the Supreme Court's requirement, see Robinson v. United States, 304 F.2d 805 (8th Cir. 1962). 
indigents in the federal courts are still burdened with many disadvantages compared with wealthy appellants, some of which are likely to affect the quality of representation afforded by appointed counsel. An indigent who wishes to appeal must apply to the trial court for leave to appeal in forma pauperis. The application must contain allegations of financial incapacity and a statement of the arguments relied upon in seeking appellate review. Because the indigent is not given the aid of counsel at this stage the application is often mexpertly prepared. This places him at a disadvantage initially since the trial court's certification is in part based on the application, and the certification is given weight by the appellate court when reviewing the trial court's denial of leave to proceed in forma pauperis. ${ }^{33}$

Perliaps the greatest burden placed on indigents in the federal courts is the lack of an adequate transcript. New counsel appointed for the appeal is required to advance reasons why the in forma pauperis appeal should be allowed, but the courts of appeals are under no duty to afford the indigent a transcript of the trial proceeding upon this appeal. ${ }^{34}$ Only if the substance of clainus made or issues sought to be raised cannot adequately be ascertained from the face of the application must a transcript be provided. Even then it need only be sufficiently complete to enable the indigent to make a showing that the trial court's certification is wrong and that he sliould be allowed to appeal in forma pauperis. ${ }^{35}$ Thus, newly appointed counsel must consult with trial counsel and often must make an independent investigation of the case in order to determine which points of error must be raised in order to obtam a transcript. If no error can be found, appointed counsel must proceed with the appeal without a transcript since he is not entitled to one in order to familiarize himself with the case and search for error ${ }^{36}$ If the court of appeals considers only error raised in the indigent's origimal application for leave to appeal in forma pauperis, counsel appointed later will have only the parts of the transcript relating to errors claimed by the indigent when he, without aid of counsel, prepared the petition for the in forma pauperis appeal.

Appoimted counsel, therefore, is burdened not only by delays due to the in forma pauperis procedure itself but also by obstacles to adequately briefing and arguing the appeal on the merits. Counsel may find it difficult to give adequate representation because of such a time-consaming process, particularly since he will receive no compensation in the federal courts.

It is evident that the in forma pauperis screening procedure places burdens on indigents not encountered by wealthy appellants with respect to both access to review and adequate representation by counsel. Although the Coppedge requirements are primarily based on an interpretation of the in forma pauperis statute, ${ }^{37}$

33 The consideration to be given the trial court's certification is unclear in view of the strict standard to be used by the courts of appeals, but the Supreme Court has stated that it is entitled to "weight" or "great weight." Coppedge v. United States, 369 U.S. 438, 446 (1962); Jobnson v. United States, 352 U.S. 565, 566 (1957).

In order to satisfy the requirements of Douglas, the trial court's certification that the appeal is not taken in good faith should create no presumption upon appellate review. Otherwise, the indigent would be burdened by a predetermination made without benefit of counsel that his appeal is without merit, exactly the procedure attacked in Douglas.

34 See Johnson v. United States, 352 U.S. 565 (1957).

35 Coppedge v. United States, 369 U.S. 438, 446 (1962).

36 See Ingram v. United States, 315 F.2d 29 (D.C. Cir. 1962).

37 See Hyser v. Reed, 318 F.2d 225, 238 (D.C. Cir. 1963). 
the Court noted Griffin and said that in requiring such equality of opportunity it had been impelled by considerations beyond the corners of the statute to provide for equal treatinent of indigents to the greatest degree possible within the statutory framework. ${ }^{38}$ Now that Douglas has emphasized the need for equality in the kind of appeal afforded, one may well consider whether the demands of equal protection can any longer be satisfied within this framework. As long as the statutory procedure exists, however, the courts of appeals can follow the suggestion of Justices Stewart and Brennan of granting leave to appeal in forma pauperis as a matter of course and then appointing counsel to brief and argue on the merits. ${ }^{30}$ Frivolous appeals of indigents and wealthy appellants would then be treated alike and disposed of by granting motions to dismiss. This practice would afford each indigent the benefit of counsel and an adequate transcript in every case and eliminate unjust delays caused by the two-step in forma pauperis procedure. ${ }^{40}$ Disadvantages suffered by indigents in these procedures cannot be justified on the grounds of avoiding floods of frivolous appeals. It has not been shown that in forma pauperis appeals are distinguishable from paid appeals with regard to merit.11 The small number of in forma pauperis appeals in the federal district courts do not place great burdens on courts or appointed counsel, so the extra burden of providing a free appeal for all indigents would not be unbearable. ${ }^{\mathbf{4 2}}$

\section{Subsequent Appellate Proceedings}

Douglas explicitly excluded from its holding any decision as to wliether counsel must be appointed when an indigent seeks a discretionary hearing before the California Supreme Court or review by the United States Supreme Court by appeal as of right or by petition for writ of certiorari. The Court, however, implied that refusal to appoint counsel in these situations might not amount to invidious

38 Coppedge v. United States, 369 U.S. 438, 446-47 (1962).

$30 \mathrm{Id}$. at 455 (concurring opinion); see also Ehrenhaft, supra note 31.

${ }^{40}$ See generally Report of the Attorney Genteral's Committee, supra note 32 . The report noted a case arising in the District of Columbia in which the defendant was indicted on Deceinber 13, 1960. After conviction and sentencing his application for leave to appeal in forma pauperis was denied by the trial court and the court of appeals. On certiorari, the Supreme Court vacated and remanded for consideration in the hight of Coppedge. After considering the appeal on the inerits, the court of appeals, on December 13, 1962, reversed and remanded with directions to enter judginent n.o.v. and discharge the appellant.

41 See Jones v. United States, 266 F.2d 924, 926 (D.C. Cir. 1959). The court notes that from September 1, 1957, to February 28, 1959, it had decided 24 appeals in which it had granted leave to appeal in forma pauperis although the district court had certified that they were not in good faith. It reversed the convictions in 11 cases, and 6 were affirmed by split decisions. Thus, in 17 of the 24 cases in which the trial court had denied leave to appeal in forma pauperis at least one judge of the appellate court thought the conviction should be reversed.

In Coppedge v. United States, 369 U.S. 438 (1962), the Court states that statistics compiled in the court below illustrate the undeniable fact that there come to that court as many meritorious in forma pauperis appeals as paid appeals and that "no a priori justification can be found for considering them, as a class, to be nuore frivolous than those in which costs have been paid." Id. at 449 .

42 The fear that allowing in forma pauperis appeals as a matter of course would engender a fiood of frivolous appeals seems to be without foundation. By far the greater number of convictions in federal district courts are on pleas of guilty or nolo contendere; and except possibly in the District of Columbia, of the criminal appeals docketed, comparatively few are taken in forma pauperis. Report of the Attorney General's Committee, supra note 32, at 92-104. 
discrimination since the indigent has already had one appeal decided on the merits with benefit of counsel. ${ }^{43}$ This limitation seems justifiable even though indigents are burdened to some extent by lack of counsel in discretionary proceedings.

Under the current practice of the United States Suprenie Court, counsel is usually never appointed to assist the indigent in the preparation of his petition for certiorari, briefs, or nemorandun in support of any other motion. ${ }^{44}$ When the indigent has filed his motion for leave to proceed in forma pauperis along with the petition for writ of certiorari, the Supreme Court will initially consider the petition for writ of certiorari without requirmg docket or advance deposit of court fees. If the petition is denied, no ruling need be made on the in forma pauperis motion. Only if the petition is granted will the Court consider the motion and will appoint counsel and procure a transcript if the decision is favorable. In the case of an indigent, therefore, the Court is usually without the aid of briefs prepared by counsel when considering whether to review the merits. ${ }^{45}$ The financially able petitioner can have the Court consider briefs prepared by his counsel before the Court decides whether to grant the writ of certiorari.46

The present California Supreme Court practice of appointing counsel for an indigent seeking a discretionary hearing is very similar to the practice of the United States Supreme Court; counsel is usually appointed only if the application for a hearing is granted. ${ }^{47}$ The court will not have the benefit of counsel's research and briefing before deciding whether to grant a hearing. Similar inequality is found in the discretionary procedures of many other state courts of last resort. ${ }^{48}$

Much the same inequality is also encountered in the United States Supreme Court practice of considering appeals as of right. Although some appellants are entitled to review as a matter of right, ${ }^{49}$ the Court disposes of a large number of these cases without briefs or oral argument ${ }^{50}$ by first requiring a jurisdictional statement and then entertaining motions to dismiss or affirm. ${ }^{51}$ Counsel is only appointed if the Court decides to hear oral argument. Since preparation of the jurisdictional statement requires legal training and since the appellant is entitled to file a brief, indigents are as burdened by their lack of counsel as in preparing petitions for certiorari.

43 The Court emphasized that it was dealing with the first appeal and the one and only appeal as of right. Douglas v. United States, 372 U.S. 353, 356-57 (1963).

44 Stern, Supreace Court Practice $\$ \S 6-11$ to 6-13 (3d ed, 1962). Appointed counsel is usually under no obligation to stay on after final action by the court of appeals. Boskey, The Right to Counsel in Appellate Proceedings, 45 MrN. L. Rev. 783, 796 (1961).

45 Only about $15 \%$ of indigents have the benefit of counsel at the time the court decides on the petition for certiorari. Stewart, The Indigent Defendant and the Supreme Court of the United States, 58 LEGAL AID REv. 3 (1960).

46 See Douglas v. California, 372 U.S. 353, 358 (1963) (Clark, J., dissenting).

${ }^{47}$ Appellate counsel, however, may voluntarily perform the duty of petitioning for rehearing and for hearing in the supreme court. If the petition is granted, the court will usually appoint the counsel who argued the appeal. Interview with Justice Peters, Associate Justice, Cahifornia Supreme Court, in San Francisco, Septenuber, 1963.

48 See Douglas v. Cahfornia, 372 U.S. 353, 360 (1963) (separate opinion of Harlan, J.). 4928 U.S.C. $\$ \S 1254,1257$ (1958).

50 " $[A] t$ least fifty per cent of the appeals are dismissed or the judgments affinned upon consideration of the jurisdictional statements before the records are printed and without oral argument." Willey, Jurisdictional Statements on Appeals to U.S. Supreme Court, 31 A.B.A.J. 239 (1945); see generally, The Supreme Court, 1961 Term, 76 HARv. L. Rev. 54, 81-82 (1962).

51 U.S. SUP. Cr. R. 15-16. 
The degree of inequality suffered by indigents, however, is not as great as at first appears. Inequality is not present as far as oral argument is concerned since petitions for hearing and certiorari are considered in conference without appearance of counsel or oral argument whether the appellant has hired counsel or not.62 Only after the petition is granted does a court hear oral argument, and by then counsel will have been appointed for the indigent. Moreover, after Douglas, most indigents will have had the benefit of counsel for their imitial appeal and can therefore submit the briefs prepared by such counsel for that appeal to the Supreme Court along with the petition for certiorari or jurisdictional statement. Although the difficulty of persuading a court that the petitioner's case merits oral argument requires expert assistance, the ultimate prejudice suffered by indigents is less in discretionary proceedings than at the first appeal, since only a small number of appeals or petitions for certiorari, whether paid or not, are heard on the merits and a smaller number yet reversed. ${ }^{53}$

Consideration must also be given to the practical burdens imposed now that equal protection has required states to appoint counsel on criminal appeals. Appointment of counsel for all indigents who seek to file petitions would impose heavy burdens on the bar and the courts. Great numbers of petitions for certiorari in forma pauperis are filed in the United States Supreme Court each year and by far the greater number of them are frivolous. ${ }^{54}$ Most of these petitions come from prisoners, and although it would be of great help to the courts to have the petitions prepared by counsel, ${ }^{55}$ neither the advantage afforded to the courts nor to the indigent seems to justify the imposition of such a burden. ${ }^{56}$

II

\section{COLLATERAI ATTACK PROCEEDINGS}

Although Douglas makes no reference to collateral proceedings, its equal protection rationale is easily extended to them. Although collateral remedies are generally considered to be civil in nature, they are obviously closely related to criminal procedures; ${ }^{57}$ and in cases where no appeal was taken or where issues raised in the collateral petition were not considered on appeal, the collateral remedy may be the first and only opportunity for review of constitutional and jurisdictional issues. Most petitions are filed in propria persona, yet most jurisdictions have not developed meaningful standards for appointing counsel. ${ }^{58}$

\footnotetext{
52 Stern, Supreme Court Practice $\$ \S 6-11$ to 6-13 (3d ed. 1962); 3 Witkin, CaIrFORNIA PROCEDURE 2408 (1st ed. 1954).

53 In the 1961 term the U.S. Supreme Court granted only $3.4 \%$ of the 1093 petitions for certiorari in forma pauperis. On the appellate docket only $13.5 \%$ of the 669 petitions for certiorari were granted. All but one of the 44 in forma pauperis appeals were summarily dismissed. The Supreme Court, 1961 Term, 76 Harv. L. REv. 54, 81 (1962). See Douglas v. Califomia, 372 U.S. 353, 358 (1963) (Clark, J., dissenting).

54 The Court dismissed about $96 \%$ of petitions for certiorari and appeals in forma pauperis without formal consideration in 1961. Ibid. See generally Douglas, The Supreme Court and Its Case Load, 45 CORNerr L.Q. 401 (1960).

55 Stewart, supra note 45 at 7.

58 It has been suggested, however, that what the sixth amendment requires of the courts of appeals it should likewise require of the Supreme Court. Boskey, supra note 44 at 798.

57 See note 66 infra.

68 See generally People v. Brown, 55 Cal. 2d 64, 69, 357 P.2d 1072, 1075, 9 Cal. Rptr. 816, 819 (Traynor, J., concurring), cert. denied, 366 U.S. 970 (1960); Boskey, supra note 44 at 799; Note, 61 Corus. L. REv. 681, 696-703 (1961).
} 
Collateral attack procedures vary greatly. They usually consist of the common law remedies of habeas corpus and coram nobis, but some jurisdictions have augmented or entirely replaced these traditional remedies with special statutory procedures. The practice with respect to appointment of counsel varies with the particular procedure.

\section{A. State Collateral Proceedings}

The problem of appointing counsel in state collateral proceedings is encountered primarily in states which have preserved the common law collateral remedies which do not embody the principles of ordimary res judicata to alleviate the burden of successive petitions by the same prisoner. The burden of considering successive petitions makes courts reluctant to appoint counsel for an indigent each time he seeks to petition.

Habeas corpus is an extraordinary post-conviction remedy generally used to gain relief from illegal confinement by testing the jurisdiction of the convicting court or the constitutionality of the conviction. ${ }^{59}$ Since it is considered a civil proceeding, separate and distinct from the criminal proceedings under which the prisoner was convicted, most states liave held that there is no constitutional right to appointment of counsel at any stage im state habeas corpus proceedings. ${ }^{60}$ In California, counsel is appointed at the discretion of the court, but usually only if the petition for the writ presents sufficient allegations and factual support to warrant the court in granting an order to show cause and providing some type of hearing. ${ }^{61}$ Thus, in California the indigent is without the aid of counsel in preparing the petition and often during the learing as well.

The coram nobis remedy lias been largely replaced by habeas corpus in most states and is now more restricted than it had been at common law. ${ }^{62}$ The states have limited the remedy to allegations based on facts not appearing in the record which if known at the trial would have required the court by law to act differently. ${ }^{63}$ When used in this manner, a coram nobis hearing may be the first trial of the factual issue presented, and an appeal may well be considered to be the first appeal as of right from the judgment. ${ }^{64}$ Moreover, althougl coram nobis is also generally considered to be a civil action ${ }^{65}$ California has considered it to be part

50 See, e.g., People ex rel. Wiseman v. Nierstheimer, 401 IIl. 260, 81 N.E.2d 900 (1948); Application of Sefton, 73 Nev. 2, 306 P.2d 771, cert. denied, 354 U.S. 914 (1957); Roehm v. Woodruff, 64 N.M. 278, 327 P.2d 339 (1958); Butt v. Graham, 6 Utah 2d 133, 307 P.2d 892 (1957).

60 See People ex rel. Ross v. Ragan, 391 IIl. 419, 63 N.E.2d 874 (1945), cert. denied, 327 U.S. 801 (1946); In re Pelke's Petition, 139 Mont. 628, 365 P.2d 936 (1961); Commonwealth ex rel. Jolinson v. Burke, $172 \mathrm{~Pa} .389,93$ A.2d 876 (1953).

61 E.g., In re Gonsalves, 48 Cal. 2d 638, 311 P.2d 483 (1957); In re Atchley, 48 Cal.2d 408, 310 P.2d 15 (1957); see also People v. Brown, 55 Cal. 2d 64, 69, 357 P.2d 1072, 1075, 9 Cal. Rptr. 816, 819 (1960) (concurring opinion).

62 Ex parte Lindley, 29 Cal. 2d 709, 177 P.2d 918 (1947); People v. Reid, 195 Cal. 249, 232 Pac. 457 (1924); Sanders v. State, 85 Ind. 318 (1882). In New York coram nobis lias become the major collateral remedy since habeas corpus is limited to jurisdictional errors. Cf. People v. Silverman, 3 N.Y.2d 200, 144 N.E.2d 10, 165 N.Y.S.2d 11 (1957). See generally Note, 61 Coldur. L. REv. 681, 692 (1961).

63 Keane v. State, 164 Md. 685, 166 Atl. 410 (1933). See People v. Gilbert, 25 Cal. 2d 422, 154 P.2d 657 (1944); People v. Lumbley, 8 Cal. 2d 752, 68 P.2d 354 (1937).

64 In Califorma denial of coram nobis is appealable as an order made after judgment. Cax. Pen. Code § 1237; People v. Martinez, 88 Cal. App. 2d 767, 199 P.2d 375 (1948).

${ }^{65}$ See People v. Gilbert, 25 Cal. 2d 422, 154 P.2d 657 (1944); State v. Ray, 111 Kan. 350, 207 Pac. 192 (1922). 
of the proceedings in the criminal case to which it relates, with respect to providing a free transcript to an indigent for a coram nobis appeal. ${ }^{66}$ Thus, in California, appeals from judgments on coram nobis petitions are very sinilar to the procedures to which Douglas is directly applicable. As yet, however, California has not considered Douglas as imposing any requirements on coram nobis appeals. ${ }^{87}$

Although Douglas is not likely to have any immediate effect on collateral proceedings, ${ }^{68}$ the extension of equal protection to right to counsel in the postconviction review area emphasizes the need for appointing counsel in those cases where fair and adequate collateral proceedings require assistance of counsel. Now that Douglas has given counsel to every indigent at the primary appellate level, perhaps some selectivity should be used in appointing counsel for collateral proceedings. The great number of habeas corpus petitions filed in state and federal courts would make appointment of counsel for every indigent seeking to petition burdensome in the extreme. ${ }^{69}$ Furthermore, most of these petitions are frivolous and are dismissed without a hearing. Those without counsel do not suffer great disadvantages since courts usually do not demand that prisoners comply with technicalities in petitioning, but only that they give a frank disclosure of the factual basis of their contentions. ${ }^{70}$ Equal protection, therefore, should not require that counsel be afforded every indigent who seeks to petition. Once a hearing is granted, however, the need for counsel becomes greater, as does the inequality suffered by the petitioner without counsel. Because of the flexibility of hearing procedures in most courts, ${ }^{71}$ there should be no absolute requirement of appointment at the hearing; the courts, however, should exercise their discretion in appointing counsel with an eye to the equality demanded for a fair procedure in Douglas.

By providing fairer and more effective collateral attack procedures the states will avoid the necessity for the use of habeas corpus by the federal courts when state post-conviction procedures have proved inadequate. Adequate representation by counsel in collateral proceedings as well as on direct appeal would sig-

66 People v. Paiva, 31 Cal. 2d 503, 190 P.2d 604 (1948).

07 In People v. Miller, 219 A.C.A. 139, 32 Cal. Rptr. 660 (1963), the court distinguished a coram nobis appeal from a direct appeal on the ground that the coram nobis remedy is purcly a court-made proceeding in the nature of a collateral attack. Counsel is appointed for appeals from coram nobis judgments at the discretion of the court. The California Supreme Court demied a hearing in Miller on October 1, 1963.

68 In Partain v. Mumicipal Court, 215 A.C.A. 477, 30 Cal. Rptr. 300 (1963), the district court apparently adopted the $H y d e$ test, see note 3 supra, for deciding whether to appoint counsel for a learing on a petition for a writ of mandate and writ of babeas corpus. The court held Douglas inapplicable to an appeal from a denial of the writs. But see Dias v. State, 155 So.2d 662 (Fla. App.1963), in which the court held that since Douglas, equal protection also requires appointment of counsel on appellate review of collateral proceedings.

69 Res judicata is generally inapplicable to habeas corpus. See Nicolay v. Kill, 161 Kan. 667, 170 P.2d 823 (1946); Sloemaker v. Dowd, 232 Ind. 602, 115 N.E.2d 443 (1953). The petition will usually be demed, lowever, when it is based on the same grounds set forth in a previous petition which was demied and there has been no change in fact or law affecting the issues or when the petition is based on grounds known but not asserted at the time of a former petition. See In re Horowitz, 33 Cal.2d 534, 203 P.2d 513 (1949); In re De La Roi, 28 Cal. 2d 264, 169 P.2d 363 (1946).

70 See People v. Brown, 55 Cal. 2d 69, 357 P.2d 1072, 1975, 9 Cal. Rptr. 816, 819 (1960) (concurring opinion); Ex parte Swan, 34 Cal.2d 300, 209 P.2d 793 (1949).

71 E.g., Lee v. Kindelan, 80 R.I. 212, 95 A.2d 51, cert. denied, 345 U.S. 1000 (1953); Whipple v. Sinith, 33 Wash. 2d 615, 206 P.2d 510 (1949). 
nificantly reduce federal interference with state criminal judgments. ${ }^{\mathbf{7 2}}$ Moreover, due to the delicate state-federal relationship in this area, federal courts are reluctant to appoint counsel for state indigent prisoners except in unusual circumstances. ${ }^{73}$ The burden thus rests with the states to provide the necessary assistance of counsel at the collateral attack level. ${ }^{74}$

In an attempt to prevent federal interference with the state administration of criminal law and to relieve the state courts from burdens in considering successive collateral attack petitions by the same prisoner, some states have enacted special statutory post-conviction remedies designed to provide a full review of constitutional issues and, by applying waiver rules, to limit the number of attacks on the conviction by the same prisoner. ${ }^{75}$ Because principles of res judicata are applied, there is a definite need for assistance of counsel in order to assure that an indigent does not unintentionally waive constitutional claims by failing to raise them at the hearing. Most states offering the procedure have met the need by providing for a right to appointment at the hearing ${ }^{76}$ and one state has also provided for counsel on appeal from the hearing decision. ${ }^{77}$ Simce a full hearing with the aid of counsel is given in every case, the indigent is gnaranteed a fair collateral proceeding. Such statutes solve the problem of hesitance to appoint counsel in habeas corpus procedures where courts have been burdened by successive petitions from the same prisoner.

\section{B. Federal Collateral Proceedings}

Separate procedures exist in the federal courts for collateral attacks on state and federal convictions. The common law remedies of habeas corpus ${ }^{78}$ and coram nobis ${ }^{79}$ are used primarily to review state convictions, while a special statutory

72 See National Association of Attorneys General, REPORT OF THE COMnMTTEE ON HABEAS Corpus, pp. 204-12 (1960), which quotes the following excerpt from a speech delivered by Justice Brennan in 1960:

It is unfortunate, but true ... that too many states' post-conviction procedures are not adequate. Indeed many which in form are adequate require representation by a skilled lawyer. Until the states provide procedures adequate to permit a hearing and adjudication of federal constitutional claims, I see no alternative but the provision of a federal habeas corpus procedure for determination of the claims.

Id. at pp. 210-11.

73 "Except under most unusual circumstances, an attorney ought not to be appointed by a federal court for the purpose of trying to find something wrong with a state judgment of conviction." Anderson v. Heinze, 258 F.2d 478, 484 (9th Cir.), cert. denied, 358 U.S. 889 (1958). See Schlette v. California, 284 F.2d 827 (9th Cir.), cert. denied, 366 U.S. 940 (1960); Nuhlenbroich v. Heinze, 281 F.2d 881 (9th Cir.), cert. denied, 365 U.S. 873 (1960).

Should this delicate state-federal relationship operate to impose burdens on the poor that are not put on the rich in these proceedings?

74 But see notes 85 and 92 infra; Fay v. Noia, 372 U.S. 391 (1963). The expanding use of federal habeas corpus indicates that the federal courts have fully accepted the burden of providing fair collateral relief where state collateral procedures prove inadequate.

75 The Oregon Post-Conviction Hearing Act replaces the common law writs and applies res judicata. ORE. REv. STAT. \$§ $138.510-680,34.330$ (1959). The nlinois Post-Conviction Hearing Act does not replace the common law writs. It was designed primarily for keeping the adjudication of constitutional issues at a local level. III. REv. STAT. ch. 38, \$§ 826-32 (1959). See generally Jenner, The Illinois Post-Conviction Hearing Act, 9 F.R.D. 347 (1950). North Carohina has enacted a similar statute. N.C. GEN. STAT. \$§ 15-217 to 222 (Supp. 1961).

76 Ore. Rev. Stat. \$ 138.590(3) (1959); Ill. Rev. Stat. ch. 38, \& 829 (1959); N.C. GeN. Stat. § 15-219 (1953). But see MD. ANN. CodE art. 27, §§ 645 A-J (Supp. 162).

77 ORE. REv. STAT. \$ 138.500 (1) (1959).

78 U.S. Const. art. I, § 9; 28 U.S.C. \$§ 2241-54 (1948).

${ }^{70}$ See United States v. Morgan, 202 F.2d 67 (2d Cir. 1953), aff'd, 346 U.S. 502 (1954). 
proceeding, 28 U.S.C. $\S 2255$ (1958), is provided as a substitute for the use of these common law remedies by federal prisoners. The procedures are substantially identical, however, since the remedy under section 2255 affords federal prisoners the same rights as they had previously enjoyed in habeas corpus proceedings. ${ }^{80}$

Courts of appeals have held that the Constitution does not require appointment of counsel in every habeas corpus proceeding since habeas corpus is considered a civil action and the sixth amendment therefore is not applicable. ${ }^{81}$ Section 2255 itself gives no right to counsel. The duty to appoint counsel varies with the particular procedure, being governed primarily by the requirements of fifth amendment due process and the proper exercise of the court's discretion. ${ }^{82}$ The federal courts generally have not appointed counsel to assist the indigent in petitioning the court. ${ }^{83}$ Furthermore, except in a small number of cases, courts have not appointed counsel for a hearing on the merits. ${ }^{84}$

The United States Supreme Court, however, has recently formulated rather rigid guides which must be used by the federal courts in determining whether to grant a full evidentiary hearimg on a habeas corpus petition. ${ }^{85}$ Since the Court has held that the same rights must be afforded in section 2255 proceedings as in habeas corpus actions, ${ }^{86}$ the mandatory hearing requirements doubtless apply also to section 2255 proceedings. The demand for these full hearings greatly increases the need for counsel. An evidentiary hearing entails a fact-finding process similar to the original trial procedure; it is, therefore, difficult to see how a prisoner can have a fair evidentiary hearing without the aid of counsel. ${ }^{87}$ Moreover, in Sanders

80 Under the statutory procedure, a motion to vacate brought in the sentencing court replaces habeas corpus petitions by federal prisoners in the nearest district court to the federal prison. The statute was seen to provide for the same previous habeas corpus rights, but in a more convenient forum. United States v. Hayman, 342 U.S. 205 (1952).

81 United States v. Wilkins, 281 F.2d 707 (2d Cir. 1960); Graeber v. Schneckloth, 241 F.2d 710 (9th Cir. 1957); Jefferson v. Heinze, 201 F. Supp. 606 (N.D. Cal. 1962). Equal protection, however, should have no less apphication to habeas corpus because of its civil nature. Smith v. Bennett, 365 U.S. 708 (1961), held that equal protection requires states to waive filing fees when an indigent seeks to apply for a writ of habeas corpus or to appeal from a habeas corpus proceeding. The Court stated that "the availability of a procedure to regain hiberty lost through criminal process cannot be made contingent upon a choice of labels." Id. at 712. See also Dillon v. United States, 307 F.2d 445 (9th Cir. 1962); Green v. United States, 158 F. Supp. 804 (D. Mass.), aff'd, 256 F.2d 483 (1st Cir. 1958).

82 Ellis v. United States, 313 F.2d 848 (7th Cir. 1963); Dillon v. United States, 307 F.2d 445 (9th Cir. 1962); United States v. Wilkins, 281 F.2d 707 (2d Cir. 1960); Anderson v. Heinze, 258 F.2d 479 (9th Cir.), cert. denied, 358 U.S. 889 (1958).

83 The petition usually must present at least "ostensible merit." E.g., Jefferson v. Heinze, 201 F. Supp. 606, 607 (N.D. Cal. 1962).

84 There is particular reluctance to appoint counsel when reviewing state convictions. Sec note 73 supra. See generally Boskey, supra note 44 at $783 \mathrm{nn} .57-58$.

85 An evidentiary hearing is required if

(1) the merits of the factual dispute were not resolved in the state hearing; (2) the state factual determination is not fairly'supported by the record as a whole; (3) the fact-finding procedure employed by the state court was not adequate to provide a full and fair hearing; (4) there is a substantial allegation of newly discovered evidence; (5) the inaterial facts were not adequately developed at the state-court hearing or (6) for any reason it appears that the state trier of fact did not afford the habeas applicant a full and fair fact hearing.

Townsend v. Sain, 372 U.S. 293,313 (1963). In other cases where the inaterial facts are disputed holding such a hearing is at the discretion of the court. Id. at 318.

${ }^{86}$ See note 80 supra.

87 The Court stated that it was the typical and not the rare case in which constitutional claims turu upon the resolution of controverted factual issues. Townsend v. Sain, 372 U.S. 293, 312 (1963). 
v. United States, ${ }^{88}$ the Court indicated that counsel should be appointed to aid the indigent when the district court is determining whether a full evidentiary hearing should be given.$^{89}$ The need for counsel would be even greater, of course, during the hearing itself.

Although assistance of counsel is necessary in these federal collateral proceedings, the increased requirements for hearings and appointment of counsel impose great burdens on the federal courts..$^{90}$ Since res judicata is not applicable to these procedures, a prisoner may usually have successive petitions considered as long as he raises soine new ground for rehef each time, ${ }^{91}$ and the United States Supreme Court has recently indicated that the federal courts should be even more liberal in allowing successive petitions. ${ }^{92}$ The courts are asked to consider great numbers of collateral petitions, and by far the greater number are frivolous. ${ }^{93}$

Certainly sonie procedure must be developed to minimize the burden imposed by affording indigents adequate representation. ${ }^{94}$ In Sanders the Court notes that the individual districts may develop their own procedure in attenipting to handle the problem of successive section 2255 motions. The Court said that judges are not required to limit the decision on the first motion to the grounds narrowly alleged but are free to adopt any appropriate means for inquiry into the legality of the prisoner's detention in order to ascertain all possible grounds upon which the prisoner might claim to be entitled to relief. At least one district judge has adopted the practice of making a pre-trial order in section 2255 proceedings that "all issues that might effect the validity of the criminal judgment and sentence be presented at this hearing." review of the conviction possible is provided in the lrope that the court will not again be required to entertain new section 2255 petitions from the same prisoner or that such petitions might be disposed of without requiring a liearing, presence of the petitioner, or appointment of counsel. Since counsel is appointed as a matter of course, the procedure presents an adequate solution to the problem of providing equal benefit of counsel at the liearing, although inequality remains at the appellate level. The procedure may not be completely effective since it may be difficult to bring before the court all possible grounds for relief that might ever be raised. It does, lowever, provide at least a partial solution to providing indigents with

88373 U.S. 1 (1963).

$89 \mathrm{Id}$ at 21.

90 See United States v. Wilkins, 281 F.2d 707 (2d Cir. 1960). Cf. Brown v. Allen, 344 U.S. 443,536 (1963) (concurring opinion).

91 Sanders v. United States, 373 U.S. 1 (1963); Waley v. Johnson, 316 U.S. 101 (1942); Frank v. Mangunı, 237 U.S. 309 (1915).

92 "Controlling weight may he given to denial of a prior application for federal laheas corpus or $\$ 2255$ relief only if (1) the same ground presented in the subsequent application was determined adversely to the appellant on the prior application, (2) the prior determination was on the inerits, and (3) the ends of justice would not he served by reaching the merits of the subsequent application." Sanders v. United States, 373 U.S. 1, 15 (1963).

93 Of the 7,041 labeas corpus petitions disposed of by the federal courts in the twelve year period ending in 1957, only 98 were successful and only 28 gained release by federal court order from state penal institutions. National Association of Attorneys General, REPORT OF THE Comantree on Habeas Corpus, p. 207 (1960). See Reitz, Federal Habeas Corpus: PostConviction Remedy for State Prisoners, 108 U. PA. L. REv. 461, 478 (1960).

04 One circuit court lias noted that if the test were equal treatment for every indigent before the bar, appointment of counsel would be required wlien any substantial issue is raised at the hearing. Dillon v. United States, 307 F.2d 445, 447 (9th Cir. 1962).

95 Carter, Pre-Trial Suggestions for Section 2255 Cases, 32 F.R.D. 393 (1963). (Emphasis added.) 
counsel and a fair procedure while mitigating the burdens of successive section 2255 motions. The procedure would also be helpful in habeas corpus review of state convictions. The fact that habeas corpus is a nonstatutory remedy should not preclude the use of such a procedure.

\section{III}

\section{CONCLUSTON}

Douglas is likely to have effects on criminal proceedings generally. From the proposition that "there can be no equal justice where the kind of an appeal a man enjoys 'depends on the amount of money he has," ${ }^{\prime 298}$ it follows that since a man's wealth has no relation to his guilt, there should be no differences in criminal procedures stemming solely from differences in wealth. The minimum requirement approach of due process is not used and it only remains to be seen whether the Supreme Court will now apply equal protection to benefit of counsel at the trial ${ }^{07}$ and in post-conviction review proceedings beyond the level of the first appeal..$^{08}$ Equal protection may also be applied to certain quasi-criminal proceedings ${ }^{09}$ and to areas other than relating to benefit of counsel, such as cost of trial preparation $^{100}$ and bail. ${ }^{101}$

96 Douglas v. California, 372 U.S. 353, 355 (1963).

97 Gideon v. Wainwright, 372 U.S. 335 (1963), was based on due process and required appointment of counsel at the trial only in felony cases. Since Douglas makes no distinction as to the seriousness of the offense, the application of equal protection to right of trial counsel may extend the right to misdemeanor cases as well.

${ }^{98}$ Since Douglas is an extension of Grifin, it should be noted that Griffin has been applied to subsequent appellate proceedings as well as to habeas corpus and coram nobis. See note 6 supra. But see note 43 supra.

${ }^{30}$ Since equal protection is an element of constitutional due process, it seems likely that the prohibition against unfair discrimination will be read into due process rights afforded by statute. In federal parole and probation revocation proceedings the due process requirements are based on statutory interpretation and not on any constitutional right, but there bas recently been an mcreased demand for fair procedure based on this statutory due process. See Robins v. Reed, 269 F.2d 242 (D.C. Cir. 1959); Moore v. Reid, 246 F.2d 654, (D.C. Cir. 1957). Due process does not now require appointment of counsel for indigent parolees at the parole revocation licaring. Hyser v. Reed, 218 F.2d 225 (1963). But it has been suggested that since poverty bears no more relation to the question of parole violation than to guilt at the trial, the discrimination against indigents in these proceedings may be so unjustifiable as to be violative of due process. Id. at 249 .

Proceedings under the California Narcotic Commitment Act, Cat. Pen. CoDE $\$ \S 6400-$ 521 , are regarded as primarily civil in nature but with criminal overtones. In re David De $\mathrm{La} \mathrm{O}$, 59 A.C. 140,378 P.2d 793, 28 Cal. Rptr. 489 (1963). However, since the proceedings and the commitinent have many penal characteristics, assistance of counsel is necessary. Although it might be argued that Douglas is not applicable since it only concerns appeals from criminal convictions, the fairest policy would be for the appellate courts to follow the Douglas mandate in these proceedings also. One difficulty is that counsel cannot be compensated since the proceedings lias not been classified as criminal, and California only provides for compensation of attorneys appointed for "any appeal or proceeding in a criminal matter." CAT. PEN. CODE $§ 1241$.

100 In the federal courts, indigents are allowed to subpoena witnesses at government expense, but the indigent must file an affidavit stating the name and address of each witness, the testimony expected, and how it is material to the defense. FED. R. CroM. P. 17(b). Thus, because of indigence, the defendant's case is often revealed to the prosecution. See Smith v. United States, 312 F.2d 867 (D.C. Cir. 1962) (statements in the affidavits are not compelled testimony and can be used to impeach the indigent).

101 Surveys indicate that a substantial number of accused persons fail to meet bail requirements. Report of the Attorney. General's Committee on Poverty and the Administration of 
But the Supreme Court in Douglas noted that "absolute equality is not required; lines can be and are drawn and we often sustain them."102 Lines must be drawn, however, on the basis of some rational purpose and proper governmental objective. ${ }^{103}$ The plinosophy of Douglas implies that no degree of discrimination is proper when it is based on wealth: the amount of money a man has has no relation to his guilt or to the merits of his case. ${ }^{104}$ Now that equal protection, lowever, has been expanded beyond prohibiting active discrimination to requiring appointment of counsel, the factors of state expense and burden on appointed counsel ${ }^{105}$ should be considered in relation to the degree of unequal opportunity encountered iu each particular procedure.

Gordon H. Van Kessel

Criminal Justice, table III, p.134 (1963). Certainly a principal factor is the financial ability of the accused. See Bandy v. United States, 81 Sup. Ct. 197, 198 (1960), wherein Justice Douglas notes that to demand a substantial bond whicb the accused is unable to secure nay raise equal protection problems. See generally Bail: An Ancient Practice Re-examined, 70 YaLE L.J. 966 (1961).

102 Douglas v. California, 372 U.S. 353, 357 (1963).

103 See Goesaert v. Cleary, 335 U.S. 464 (1948); Tiger v. Texas, 310 U.S. 141 (1940).

104 But see Norvell v. Mlinois, 373 U.S. 420,423 (1963).

105 Currently, counsel appointed by the federal courts receive no compensation for their services. The United States Supreme Court pays only the cost of printing the briefs and attorney's transportation. U.S. SuP. CT. R. 53. Many bills have been introduced in Congress designed to nake funds available to the individual districts either to pay private counsel or to establisb public defender systems. During the 87th Congress five such bills were introduced, none of which was passed by both houses. S. 655 87th Cong., 1st Sess. (1961) ; S. 854, 87th Cong., 1st Sess. (1961) ; S. 1484, 87th Cong., 1st Sess. (1961) ; H.R. 2696, 87th Cong., 1st Sess. (1961) ; S. 2900, 87th Cong., 2d Sess. (1962). A similar bill was introduced in the 88th Congress which was recommended by the Attorney General's Committee on Poverty and the Administration of Criminal Justice after nuch research and investigation. H.R. 5881, 88th Congress, 1st Sess. (1963). The bill provides for the institution of federal defender systems and for compensation of private counsel not exceeding $\$ 15$ per hour. It provides for representation "through appeal." For an analysis of statutory proposals see Note, 76 HARv. L. REv. 579, 607 (1963).

Assigned counsel and public defender systems co-exist in California. See Note, 13 Stan. L. REv. 522 (1961). Counsel appointed in California to represent a party to any appeal or proceeding in a criminal matter is entitled to a reasonable fee. Car. Pen. Code $\$ 1241$. See generally Note, 49 CAL. L. REv. 954 (1961). The fees are generally inadequate, particularly in death penalty cases which put extensive demands on appointed counsel. REPORT OF THE National Association of Defense Lawyers to Senator Regan and Assemblyman Wintox (1963) indicates a great disparity between fees paid to appointed counsel in death penalty cases and what these counsel believe would have been a reasonable fee.

Although appointed counsel are generally considered as conscientious as hired counsel, lack of adequate compensation often operates to discourage experienced attorneys from handling indigent cases so that indigents nust settle for young and inexperienced counsel. See generally Douglas, In Forma Pauperis Practice in the United Siates, N.H.B.J. 5, 10 (1959). The burden of providing representation for indigents now rests primarily upon a small segment of society: the bar and particularly criminal attorneys. Now that the states and federal courts have been required to appoint counsel for indigents autounatically both at the trial and on appeal, greater consideration nuust be given to the problem of who slould bear the increased cost of free counsel. 